\title{
Lacrimal immunoglobulins and complement quantified by counter-immunoelectrophoresis
}

\author{
RODNEY BLUESTONE, DAVID L. EASTY, LEONARD S. GOLDBERG, \\ BARRIE R. JONES, AND THOMAS H. PETTIT \\ From the Medical and Research Services, Wadsworth Hospital Center, Los Angeles, California; Departments of Medicine \\ and Ophthalmology, UCLA School of Medicine, Los Angeles, California; and the Institute of Ophthalmology, University \\ of London
}

Immunoglobulins present in external secretions are thought to play a major role in the body's surface defence against infective organisms (Tomasi and DeCoteau, 1970). This defence mechanism has been demonstrated in lacrimal and conjunctival secretions (tears) where local humoral immunity appears to be important (Centifanto and Kaufman, I970). However, previous studies on the immunoglobulin concentrations in tears have yielded variable results (Little, Centifanto, and Kaufman, 1969; Josephson and Weiner, 1968; Knopf, Bertran, and Kapikian, I 970; McClellan, Whitney, Newman, and Allansmith, I973).

The methods for collecting tears sometimes induce excessive lacrimation thereby diluting the total protein concentrations. Hence previous results expressed as milligrams of immunoglobulin per Ioo millilitres may not be satisfactory. Furthermore, the methods for measuring immunoglobulins in tears frequently use the relatively intensitive radial immunodiffusion technique. Moreover, the major immunoglobulin in tears appears to be IIS or secretory IgA (Franklin, Kenyon, and Tomasi, 1973; Lai A. Fat, Suurmond, and Van Furth, 1973), yet the standard protein used in these assay systems is often the $7 \mathrm{~S}$ or serum IgA.

We have measured tear and matched serum immunoglobulin and complement concentrations in samples collected from normal volunteers and patients suffering from various ocular diseases. Tears were obtained by both direct (capillary tube) and indirect (eluted) means. A new, sensitive, electroimmunodiffusion assay was used and results were expressed with respect to a constant reference base$\mu \mathrm{g}$ immunoglobulin per mg protein.

\section{Methods}

Tears from 13 people (five normal subjects; eight with

Address for reprints: R. Bluestone, Rheumatology Section, Medical Service, Veterans Administration, Wadsworth Hospital Center, Wilshire and Sawtelle Boulevards, Los Angeles, California 90073, USA. miscellaneous eye diseases) were collected by two methods. Undiluted collections were made from the lower palpebral conjunctiva by carefully applied capillary tubes $(0.5 \mathrm{~mm}$ internal diameter). The filled capillary tubes (containing 50 to $70 \mu \mathrm{l}$ ) were placed in sealed containers. Diluted collections were obtained by gently applying Schirmer strips to the lower conjunctival sac. After being allowed to absorb tears, the paper was removed and stored in a sealed Io $\times 75 \mathrm{~mm}$ plastic tube. All samples were stored for up to 6 months at $-70^{\circ} \mathrm{C}$ until tested. Before testing, the filter papers were individually eluted with a minimal volume of phosphate-buffered saline (PBS) $\mathrm{pH} 7 \cdot 3$ to a total volume of 37 to $75 \mu$ l.

Total protein concentrations were determined using the method of Lowry, Rosebrough, Farr, and Randall (I95I). Tear and serum immunoglobulin assays were performed using an electroimmunodiffusion technique incorporating a cellulose acetate membrane ('Cellogel') (Watkins, Atkins, and Holborow, r97I). Only one surface of this membrane is penetrable by protein solutions thus allowing more sharply defined sample application and more distinctly separated zones on electrophoresis. The assay system is particularly suitable for measuring immunoglobulins present at low dilutions in various biological fluids. Commercial antisera monospecific for human IgG, IgA, and IgM were obtained from Kallestad Labs, Inc. (Minneapolis, Minnesota), for IgD from Meloy Labs, Inc. (Springfield, Virginia), and for $\mathrm{B}_{1} \mathrm{G}$ from Hyland Labs, Inc. (Costa Mesa, Galifornia). Antiserum to human colostral IgA was prepared as previously described (Bluestone, Gumpel, Goldberg, and Holborow, 1972). The prepared antiserum was absorbed with serum from a person with selective absence of $\operatorname{IgA}$; this absorbed antiserum reacted with secretory piece and with IgA. The values obtained with the antiserum were taken to represent secretory IgA since the vast majority of secretory piece in exocrine fluids is bound to IgA. All antisera were diluted $I: 2$ in 0.1 molar PBS before application. Purified human IgG, IgA, IgM, and colostral IgA were used as antigen standards. Standards for IgD and $B_{1} G$ were those provided by the commercial sources of antisera. A wide range of various concentrations of all the antigens were utilized as standards in the assays; from 30 to $960 \mu \mathrm{g} / \mathrm{ml}$ for tears and from 260 to 9000 og/ml for sera. Tear immunoglobulin and complement concentrations were expressed as $\mu \mathrm{g} / \mathrm{mg}$ of protein. Using this assay system, tear immunoglobulin concentrations down to $30 \mu \mathrm{g} / \mathrm{mg}$ protein were measurable. 
This sensitivity compares favourably with previous use of the assay system applied to human saliva and mouse serum and urine (Bluestone and others, 1972; Bluestone, Goldberg, Kalmanson, and Guze, 1973).

\section{Results}

All results are shown in the Table. Tear samples collected by direct capillary action ('neat') usually contained slightly more protein than those eluted from filter paper. However, by using protein concentration as the standard reference base, both methods of sampling yielded comparable results.

The predominant tear immunoglobulin was secretory IgA, which was detectable in all 13 subjects and easily measurable in 12 ; the mean concentration was $107 \mu \mathrm{g} / \mathrm{mg}$ protein (standard error of mean 15) in 17 samples obtained from 13 subjects. The concentrations of $\operatorname{IgA}$ in tears frequently exceeded those in matched sera and presumably reflected the presence of large amounts of secretory $\operatorname{IgA}$.

IgG was present in most tears but only measurable in three cases (one normal, two with eye disease); in these three, the concentrations of IgG in tears were lower than those detected in serum. No IgM or IgD was detected in any tear sample.

Complement $\left(\mathrm{B}_{\mathbf{1}} \mathrm{C}\right)$ was detected and measured in seven tear samples (four normal; three with eye disease) and was always present in lower concentrations than the corresponding serum.

\section{Discussion}

This study has demonstrated a highly satisfactory method for measuring tear immunoglobulin and complement concentrations. The protein content of the tears was readily measurable and was similar to previously described values (Schultze and Heremens, I 966$)$. Moreover, by using the total protein content as a standard reference base, direct comparisons between tear and serum content were facilitated regardless of the degree of dilution induced by excessive lacrimation.

The results confirm earlier observations which suggest that secretory (I IS) IgA is the predominant tear immunoglobulin (Knopf and others, I970; McClellan and others, 1973; Franklin and others, 1973; Lai A Fat and others, 1973); and, for the first time, provide a more precise measurement of that antibody in lacrimal fluid. Moreover, the amounts of IgA per milligram of protein detected (predominantly as secretory $\operatorname{IgA}$ ) in the present study are roughly comparable with the values obtained by other investigators measuring $7 \mathrm{~S} \mathrm{IgA}$ in both tears and aqueous humour (McGlellan and others, 1973; Allansmith, Whitney, McClellan, and Newman, 1973). The values obtained for monomeric IgA and for secretory IgA in tears were comparable in most cases. However, in five samples the amounts of secretory IgA detected were far higher than the level of monomeric antibody. There are two possible

Table Tear and serum immunoglobulin and complement concentrations in 13 subjects

Subject* Total protein, immunoglobulin and complement concentrations** Tears

\begin{tabular}{|c|c|c|c|c|c|}
\hline & $T P$ & $G$ & $A$ & $M$ & $S A^{* * *}$ \\
\hline I $\mathrm{n}$ & $2 \cdot 1$ & 53 & 59 & o & I 14 \\
\hline $\mathrm{e}$ & $I \cdot 5$ & $<3^{8}$ & $<3^{0}$ & o & I I9 \\
\hline $2 n$ & 0.7 & $\mathbf{O}$ & $<30$ & $\mathbf{O}$ & 216 \\
\hline e & $1 \cdot 8$ & $<3^{8}$ & n.d. & n.d. & 76 \\
\hline $3 n$ & $\mathbf{I} \cdot \mathbf{O}$ & $<38$ & $<_{30}$ & $\mathbf{O}$ & 80 \\
\hline e & $0 \cdot 6$ & $<38$ & n.d. & n.d. & 100 \\
\hline $4 n$ & $I \cdot 6$ & $<38$ & $6_{3}$ & $\mathbf{O}$ & 81 \\
\hline e & $0 \cdot 6$ & $<3^{8}$ & n.d. & $\mathbf{O}$ & 133 \\
\hline 5 & $2 \cdot 6$ & $\mathbf{O}$ & $<30$ & o & 73 \\
\hline 6 & $2 \cdot I$ & 44 & 124 & o & $4^{8}$ \\
\hline 7 & $2 \cdot 7$ & n.d. & 54 & O & I I 9 \\
\hline 8 & $I \cdot O$ & $<38$ & 85 & 0 & $5^{\circ}$ \\
\hline 9 & $\mathbf{I} \cdot \mathbf{O}$ & $<38$ & 66 & 0 & 60 \\
\hline IO & 0.5 & $<38$ & $<30$ & $\mathbf{O}$ & 90 \\
\hline I I & $2 \cdot 5$ & 44 & I 47 & o & 92 \\
\hline 12 & $0 \cdot 1$ & $<38$ & $<30$ & o & 40 \\
\hline 13 & $\mathbf{I} \cdot \mathbf{O}$ & n.d. & 65 & $\mathbf{O}$ & 120 \\
\hline
\end{tabular}

Serum

\begin{tabular}{|c|c|c|c|c|c|c|c|}
\hline$D$ & $B_{1} C$ & $T P$ & $G$ & $A$ & $M$ & $D$ & $B_{1} C$ \\
\hline 0 & 14 & 65 & I 85 & 46 & 12 & 0.5 & 246 \\
\hline o & o & & & & & & \\
\hline 0 & o & 62 & I 45 & 47 & 12 & $0 \cdot 7$ & 113 \\
\hline n.d. & 60 & & & & & & \\
\hline $\begin{array}{l}\text { o } \\
\text { n.d. }\end{array}$ & $\begin{array}{l}80 \\
\text { n.d. }\end{array}$ & 64 & I 33 & 29 & 10 & $0 \cdot 9$ & 547 \\
\hline 0 & I 3 & 62 & I33 & 24 & 9 & 0.5 & 287 \\
\hline $\mathbf{O}$ & o & & & & & & \\
\hline 0 & 24 & 67 & I 49 & 57 & II & 0.5 & 269 \\
\hline 0 & 71 & 74 & 203 & 60 & $5 \cdot 3$ & $1 \cdot 4$ & 46 \\
\hline O & n.d. & 80 & 206 & 90 & 10 & $3 \cdot 8$ & 36 \\
\hline $\mathbf{O}$ & 0 & 83 & I 93 & 65 & $10 \cdot 8$ & $2 \cdot 2$ & 343 \\
\hline 0 & 80 & 68 & 132 & 63 & 9.3 & $I \cdot 2$ & 419 \\
\hline o & 0 & 85 & 141 & 53 & 9 & $2 \cdot 2$ & 447 \\
\hline $\mathbf{O}$ & o & 75 & 100 & 53 & I I 6 & 0.7 & 44 \\
\hline 0 & o & 65 & 215 & 85 & $4^{\cdot 6}$ & $2 \cdot 3$ & 46 \\
\hline 0 & o & $5^{8}$ & 164 & 18 & $6 \cdot 6$ & n.d. & 34 \\
\hline
\end{tabular}
* Subjects 1-5 normal volunteers; 6-13 with various eye diseases. Neat (n) and eluted (e) tears obtained from subjects $1-4$; neat tears only

** Total protein, mg per $\mathrm{ml}$; immunoglobulins and complement, $\mu \mathrm{g} / \mathrm{mg}$ of protein 
explanations for this disparity; the tears may have contained increased amounts of free secretory piece, or the antiserum was not specific for secretory IgA but indeed detected other, unrecognized, proteins present in lacrimal secretions.

Previous studies in this field have reported variable amounts of IgG in tears (Little and others, 1969; Josephson and Weiner, 1968; Knopf and others, 1970; McClellan and others, 1973); our results indicate that IgG antibody is usually detectable, but only occasionally quantifiable, in tears from normal and diseased eyes. Interestingly, a recent report by Chandler, Leder, Kaufman, and Caldwell (1974) described a relatively sensitive electroimmunodiffusion technique for measuring tear immunoglobulins. However, that study was not applied to the specific assay of secretory IgA; and IgG was absent or detected in only very small amounts in tears from normal subjects. The absence of $\operatorname{IgM}$ and $\operatorname{IgD}$ in the tears we studied is in accord with earlier reports (Aiuti, Turbessi, and Ugolini, 1969).

The presence of definite amounts of tear complement (measured as the third component- $B_{1} G$ ) in approximately half the samples is in accordance with recent observations using a haemolytic assay (Allansmith and others, 1973). Tear complement concentrations might well provide a useful indicator for future studies on humoral immune-mediated eye disease.

\section{Summary}

Immunoglobulin and complement concentrations of tears were measured using a sensitive electroimmunodiffusion assay. In the 13 subjects tested, the predominant immunoglobulin was secretory IgA (mean concentration $107 \mu \mathrm{g} / \mathrm{mg}$ protein; standard error of mean $15 ; n=17$ ). The $\mathrm{B}_{1} \mathrm{C}$ component of complement was measurable in half of the subjects studied. The data illustrate that it is possible to quantify exactly certain humoral indices which may be important in the host defence of the eye.

The skilled technical assistance of Mr W. J. Mills is gratefully acknowledged. The work was partly supported by grants from US Public Health Service (GM 15759) and Kroc Foundation.

\section{References}

AIUTI, F., TURBessi, G., and Ugolini, A. (1969) Experientia (Basel), 25, 1089

ALlANSmith, M. R., Whitney, C. R., MCCLeli.AN, B. H., and NEWMAN, L. P. (1973) Arch. Ophthal. (Chicago), 89, 36

Bluestone, R., goldberg, L. s., Kalmanson, G. m., and Guze, L. B. (1973) Int. Arch. Allerg., 45, 57 I

-, GUMPEL, J. M., GOLDBERG, L. S., and HOLBOROW, E. J. (1972) Ibid., 42, 686

CENTIFANTO, Y. M., and KAUfMAN, H. E. (1970) Infect. and Immun., 2, 778

GHANDLER, J. W., LEDER, R., KAUfMAN, H. E., and CALDWELl, J. R. (1974) Invest. Ophthal., 13, I5I

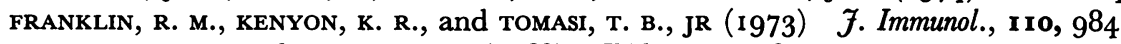

JOSEPHSON, A. S., and WEINER, R. S. (1968) Ibid., 100, 1080

KNOPF, H. L. s., BERTRAN, D. M., and KAPIKIAN, A. z. (1970) Invest. Ophthal., 9, 727

LAI A FAt, R. F. M., SUURMOND, D., and VAN FURTh, R. (1973) Clin. exp. Immunol., 14, 377

little, J. M., centifanto, y. m., and kaufman, H. e. (1969) Amer. F. Ophthal., 68, 898

LOWRY, O. H., ROSEBrough, N. J., FARR, A. L., and RANDALL, R. J. (1951) F. biol. Chem., 193, 265

MCGLELLAN, B. H., WhitNey, C. R., NEWMAN, L. P., and ALlansmith, M. R. (1973) Amer. F. Ophthal., 76, 89

SCHultze, H. E., and heremens, J. F. (1966) 'Molecular Biology of Human Proteins', vol. I, p. 873.

Elsevier, Amsterdam

TOMASI, T. B., and DeCoteAU, E. (1970) Advanc. intern. Med., 16, $40 \mathrm{O}$

watkins, J.: Atkins, B., and holborow, E. J. (1971) F. clin. Path., 24, 665 